\title{
Assessment of mineral content of various bottled water marketed in Saudi Arabia
}

\author{
A. M. Al-Omran, S. E. El-Maghraby, Z. Al-Asmari, \\ M. E. A. Nadeem \& A. El-Eter \\ Soil Science Department, King Saud University, Riyadh, Saudi Arabia
}

\begin{abstract}
Fifty-two brands of domestic bottled water were collected during the first quarter of the year 2011 from the supermarkets and food stores in Riyadh city, Saudi Arabia. The collected water was evaluated for their mineral content and the results were compared with the mineral content label on each bottle and/or with drinking water standards of either Saudi Arabia or the WHO. Evaluation included $\mathrm{pH}$, TDS, soluble $\mathrm{Ca}^{2+}, \mathrm{Mg}^{2+}, \mathrm{Na}^{+}, \mathrm{K}^{+}, \mathrm{NO}_{3}{ }^{-}, \mathrm{Cl}^{-}, \mathrm{SO}_{4}{ }^{2-}$ as well as the concentrations of $\mathrm{As}, \mathrm{B}, \mathrm{Be}, \mathrm{Cd}, \mathrm{Co}, \mathrm{Cr}, \mathrm{Cu}, \mathrm{Fe}, \mathrm{Mn}, \mathrm{Mo}, \mathrm{Ni}, \mathrm{Pb}, \mathrm{Se}, \mathrm{Sr}, \mathrm{Ti}, \mathrm{V}$, $\mathrm{Zn}$ and $\mathrm{BrO}_{3}^{-}$. The obtained results indicated that except $\mathrm{NO}_{3}{ }^{-}, \mathrm{F}$ and $\mathrm{BrO}_{3}^{-}$the concentrations of TDS, $\mathrm{Ca}^{2+}, \mathrm{Mg}^{2+}, \mathrm{Na}^{+}, \mathrm{K}^{+}, \mathrm{NO}_{3}{ }^{-}, \mathrm{Cl}^{-}, \mathrm{SO}_{4}{ }^{2-}$ and trace elements of most collected water agree well with the permissible limits set either by WHO or Saudi Arabian standards but with some variation for some major values. The result indicated the determined values of $\mathrm{pH}$ values are in agreement with the reported label values. On the other hand results of $\mathrm{BrO}_{3}^{-}$indicate that more than $18 \%$ of the total collected bottled water exceeded the allowable limits of Bromate $(10 \mu \mathrm{g} / \mathrm{L})$ according to Saudi Arabia Standards and WHO. Furthermore, comparison of the analytical results with the mineral content labeled in each bottle revealed a substantial variation in the parameter values, and that the reported label values of most parameters do not reflect the real content of the bottles.
\end{abstract}

Keywords: bottled water, mineral composition, Bromate, drinking water quality, bottled water standards. 


\section{Introduction}

The periodical analysis of bottled drinking water is very essential to ensure that water is safe and can be consumed by humans. In this respect, Guler [1] found a significant number of bottled water brands in Turkey contained $\mathrm{Na}, \mathrm{Cl}, \mathrm{SO}_{4}, \mathrm{~F}$, polycyclic aromatic hydrocarbons and several heavy metals above the maximum concentration allowed for bottled waters either by Turkish legislation or other international organizations. Also, Baba et al. [2] came to the same results that bottled Turkish water has differences in their chemical composition and the majority of bottled water exceeded the $\mathrm{pH}$ limit of Turkish drinking water standards. Guler and Alpaslan [3] revealed that the analysis of 70 samples of bottled water collected from a Turkish market showed that the measured As concentration in one brand was more than three times the standard value set by EC and WHO. Khan and Chohan [4] pointed out that the mean level of F, Ca, and $\mathrm{pH}$ in bottled water in Saudi Arabia were significantly higher than reported on the labels. With respect to bromated concentration, Othman et al. [5] indicated that $30 \%$ of the samples of bottled drinking water in the Saudi Arabia market are acceptable as US EPA standards $\left(10 \mu \mathrm{gL}^{-1}\right), 40 \%$ of the samples are acceptable as Saudi standards $\left(25 \mu \mathrm{gL}^{-1}\right)$, and moreover $60 \%$ of the samples exceed the allowable limits for bromated in drinking bottled water. The objective of this study was to compare the accuracy of the concentration of minerals contents mentioned at the manufacturer labels of different bottled drinking water in Riyadh, Saudi Arabia. As well as to compare the chemical composition of such bottled water with drinking water standards of Saudi Arabian, USA and WHO.

\section{Material and methods}

Fifty-two different brands of locally produced bottled drinking water were collected during the $1^{\text {st }}$ quarter of the year 2011 from the supermarkets and food stores in Riyadh city, Saudi Arabia. All bottles were stored in a dark place and in their original closed plastic containers at room temperature. The samples were analyzed for $\mathrm{EC}, \mathrm{pH}, \mathrm{Ca}^{2+}, \mathrm{Mg}^{2+}, \mathrm{Na}^{+}, \mathrm{K}^{+}, \mathrm{Cl}^{-}, \mathrm{SO}_{4}{ }^{2-}, \mathrm{NO}_{2}{ }^{2-}, \mathrm{NO}_{3}{ }^{-}$and $\mathrm{F}$ according to Matiti [6]. The bromate $\mathrm{BrO}_{3}{ }^{-}$in the bottled drinking water has been investigated using liquid chromatography (ICS-3000 Ion Chromatography System). Also, the concentration of As, B, Be, Cd, Co, Cr, Cu, Fe, Mn, Mo, Ni, $\mathrm{Pb}, \mathrm{Se}, \mathrm{Sr}, \mathrm{Ti}, \mathrm{V}$, and $\mathrm{Zn}$ in the collected bottled water was determined using the ICP-Perkin Elmer Model 4300DV).

\section{Results and discussions}

Results in Tables 1 and 2 show that the compositions of the collected drinking bottled water are very different in character, and display a wide range of parameter values. There is a great difference between the determined values of each parameter and the respective value labeled in each bottle. The concentration ranged (in mg. $\mathrm{L}^{-1}$ ) from $0.02-41.88$ for $\mathrm{Ca}$; 0.04-22.0 for $\mathrm{Mg}$; $0.30-69.8$ for $\mathrm{Na}$; 
0.02-13.4 for $\mathrm{K} ; 0.09-88$ for $\mathrm{Cl}^{-} ; 0.05-5$ for $\mathrm{F}$; $0.0-35.72$ for $\mathrm{NO}^{-}$; $0.0-90.5$ for $\mathrm{SO}_{4}{ }^{2-} ; 1.3-135.22$ for $\mathrm{HCO}_{3}{ }^{-} ; 0.0-0.033$ for As; $0.019-1.656$ for $\mathrm{B} ; 0.0-0.002$ for $\mathrm{Cd}$; $0.0-0.005$ for $\mathrm{Co}$; $0.0-0.004$ for $\mathrm{Ni}$; $0.0-0.086$ for $\mathrm{Se}$; $0.0-0.382$ for $\mathrm{Sr}$ and $0.0-0.024 \mathrm{mgL}^{-1}$ for $\mathrm{Pb}$. The maximum concentrations of $\mathrm{Na}, \mathrm{NO}_{3}{ }^{-}, \mathrm{NO}_{2}{ }^{-}$, $\mathrm{SO}_{4}{ }^{2-}, \mathrm{Cl}^{-}$, and $\mathrm{F}^{-}$were higher than the respective $\mathrm{KSA}, \mathrm{WHO}$ and USA permissible limits (Tables 1 and 2). On the other hand, the $\mathrm{Ca}, \mathrm{Mg}, \mathrm{K}, \mathrm{HCO}_{3}{ }^{-}$, $\mathrm{Se}, \mathrm{Sr}, \mathrm{Ti}, \mathrm{V}$ and Bromide were detected in all collected bottled water samples, however, no permissible limits were available for comparing these parameters either with KSA, WHO or USA.

Table 1: Comparing the analytical composition of drinking bottled water with what is written on the label.

\begin{tabular}{|c|c|c|c|c|c|c|c|}
\hline \multirow{2}{*}{ Property } & \multirow{2}{*}{ unit } & \multicolumn{3}{|c|}{ Determined } & \multicolumn{3}{c|}{ On the Label } \\
\cline { 3 - 8 } & --- & 7.480 & 6.700 & 8.440 & 7.20 & 6.70 & 7.50 \\
\hline $\mathrm{pH}$ & $\mathrm{mg} / \mathrm{l}$ & 126.098 & 43.00 & 235.000 & 122.63 & 43.00 & 235.00 \\
\hline $\mathrm{TDS}$ & $\mathrm{mg} / \mathrm{l}$ & 13.401 & 0.019 & 41.880 & 14.31 & 0.30 & 40.00 \\
\hline $\mathrm{Ca}$ & $\mathrm{mg} / \mathrm{l}$ & 3.912 & 0.038 & 22.000 & 4.33 & 0.50 & 22.00 \\
\hline $\mathrm{Mg}$ & $\mathrm{mg} / \mathrm{l}$ & 20.541 & 0.300 & 69.750 & 18.23 & 0.30 & 35.00 \\
\hline $\mathrm{Na}$ & $\mathrm{mg} / \mathrm{l}$ & 1.370 & 0.018 & 13.400 & 1.62 & 0.10 & 13.40 \\
\hline $\mathrm{K}$ & $\mathrm{mg} / \mathrm{l}$ & 32.483 & 0.090 & 88.000 & 26.25 & 2.60 & 88.00 \\
\hline $\mathrm{CL}$ & $\mathrm{mg} / \mathrm{l}$ & 34.720 & 1.300 & 135.217 & 32.88 & 1.30 & 120.00 \\
\hline $\mathrm{HCO}{ }_{3}$ & $\mathrm{mg} / \mathrm{l}$ & 23.266 & 0.000 & 90.466 & 21.91 & 0.00 & 51.00 \\
\hline $\mathrm{SO}_{4}$ & $\mathrm{mg} / \mathrm{l}$ & 5.731 & 0.000 & 35.718 & 3.40 & 0.00 & 20.00 \\
\hline $\mathrm{N}-\mathrm{NO}_{3}$ & $\mathrm{mg} / \mathrm{l}$ & 1.040 & 0.050 & 5.000 & 0.89 & 0.05 & 5.00 \\
\hline $\mathrm{F}$ & $\mu \mathrm{g} / \mathrm{l}$ & 4.733 & 0.000 & 111.600 & 1.76 & 0.00 & 9.99 \\
\hline $\mathrm{BrO}_{3}$ & & & & &
\end{tabular}

The concentration of $\mathrm{BrO}_{3}^{-}$were so much higher than Permissible limits $(10 \mu \mathrm{g} / \mathrm{l})$ set either by KSA, WHO [7] and USA. Furthermore, analyses of bromated indicated that more than $18 \%$ of the samples had higher limits compared to the Saudi Arabia standards $(25 \mu \mathrm{g} / \mathrm{L}), 30 \%$ of the samples had higher limits of F compared to the Saudi Arabia standards $(1.5 \mathrm{mg} / \mathrm{L})$, and about $20 \%$ of the samples had higher limits of $\mathrm{N}-\mathrm{NO}_{3}$ compared to the Saudi Arabia standards $(10 \mathrm{mg} / \mathrm{L})$.on the other hand, the maximum concentrations of As, Be, $\mathrm{Cd}, \mathrm{Cr}, \mathrm{Cu}, \mathrm{Fe}, \mathrm{Mn}, \mathrm{Mo}, \mathrm{Ni}$, and $\mathrm{Zn}$ in bottled water samples, were below their respective values according to the KSA stander, and WHO. However, special attention should be paid to As, since measured arsenic concentration in one sample (brand \#7) was nearly four times the standard value set by KSA.

Comparing the obtained results with the reported label in each bottle data in Tables 1 and 2 indicated that the mean concentrations of analytical and labeled values are relatively close for most parameters, but they are generally somewhat 
higher than the values reported on the bottled labels. However, no data were found on the bottled labels for $\mathrm{NO}_{2}{ }^{-}, \mathrm{Si}, \mathrm{Ba}, \mathrm{Br}, \mathrm{Co}, \mathrm{Mo}, \mathrm{Sr}$, Ti and $\mathrm{V}$, therefore, we could not compare such parameters.

Table 2: Chemical composition of drinking bottled water in relation to the other permissible limits.

\begin{tabular}{|c|c|c|c|c|c|c|c|c|}
\hline \multirow[t]{2}{*}{ Property } & \multirow[t]{2}{*}{ Unit } & \multirow[t]{2}{*}{ Mean } & \multirow[t]{2}{*}{ Min } & \multirow[t]{2}{*}{ Max } & \multirow[t]{2}{*}{ S. D } & \multicolumn{3}{|c|}{ Permissible limits } \\
\hline & & & & & & KSA & WHO & USA \\
\hline Nitrite & $\mathrm{mg} / \mathrm{l}$ & 0.005 & 0.000 & 0.033 & 0.006 & 3 & ---- & 1 \\
\hline Bromide & $\mathrm{mg} / \mathrm{l}$ & 0.082 & 0.014 & 0.680 & 0.091 & --- & --- & --- \\
\hline $\mathrm{Al}$ & $\mathrm{mg} / \mathrm{l}$ & 0.007 & 0.000 & 0.145 & 0.021 & 0.2 & 0.2 & $-\cdots$ \\
\hline As & $\mathrm{mg} / \mathrm{l}$ & 0.003 & 0.000 & 0.033 & 0.007 & 0.01 & 0.05 & 0.05 \\
\hline B & $\mathrm{mg} / \mathrm{l}$ & 0.327 & 0.019 & 1.656 & 0.349 & 0.5 & $-\cdots-$ & $-\cdots$ \\
\hline $\mathrm{Ba}$ & $\mathrm{mg} / \mathrm{l}$ & 0.004 & 0.000 & 0.061 & 0.008 & 0.7 & $-\cdots$ & $-\cdots$ \\
\hline $\mathrm{Be}$ & $\mathrm{mg} / \mathrm{l}$ & 0.000 & 0.000 & 0.000 & 0.000 & 1 & --- & $-\cdots$ \\
\hline $\mathrm{Cd}$ & $\mathrm{mg} / \mathrm{l}$ & 0.000 & 0.000 & 0.002 & 0.000 & 0.003 & 0.005 & 0.05 \\
\hline Co & $\mathrm{mg} / \mathrm{l}$ & 0.001 & 0.000 & 0.005 & 0.001 & $\begin{array}{ll}--- \\
\end{array}$ & --- & $\begin{array}{ll}--- \\
\end{array}$ \\
\hline $\mathrm{Cr}$ & $\mathrm{mg} / \mathrm{l}$ & 0.001 & 0.000 & 0.009 & 0.001 & 0.05 & 0.05 & 0.1 \\
\hline $\mathrm{Cu}$ & $\mathrm{mg} / \mathrm{l}$ & 0.000 & 0.000 & 0.001 & 0.000 & 2 & 1.3 & 1.3 \\
\hline $\mathrm{Fe}$ & $\mathrm{mg} / \mathrm{l}$ & 0.001 & 0.000 & 0.002 & 0.001 & 0.3 & 0.3 & 0.3 \\
\hline $\mathrm{Mn}$ & $\mathrm{mg} / \mathrm{l}$ & 0.000 & 0.000 & 0.002 & 0.000 & 0.1 & 0.2 & 0.05 \\
\hline Mo & $\mathrm{mg} / \mathrm{l}$ & 0.002 & 0.000 & 0.009 & 0.002 & 0.07 & ---- & ---- \\
\hline $\mathrm{Ni}$ & $\mathrm{mg} / \mathrm{l}$ & 0.000 & 0.000 & 0.004 & 0.001 & 0.02 & ---- & ---- \\
\hline $\mathrm{Pb}$ & $\mathrm{mg} / \mathrm{l}$ & 0.008 & 0.000 & 0.024 & 0.007 & 0.01 & 0.05 & \\
\hline $\mathrm{Se}$ & $\mathrm{mg} / \mathrm{l}$ & 0.008 & 0.000 & 0.086 & 0.017 & 0.01 & 0.01 & \\
\hline $\mathrm{Sr}$ & $\mathrm{mg} / \mathrm{l}$ & 0.105 & 0.000 & 0.382 & 0.085 & --- & --- & ---- \\
\hline $\mathrm{Ti}$ & $\mathrm{mg} / \mathrm{l}$ & 0.000 & 0.000 & 0.000 & 0.000 & $-\cdots$ & ---- & ---- \\
\hline $\mathrm{V}$ & $\mathrm{mg} / \mathrm{l}$ & 0.000 & 0.000 & 0.010 & 0.001 & $-\cdots$ & ---- & $\begin{array}{l}--- \\
\end{array}$ \\
\hline $\mathrm{Zn}$ & $\mathrm{mg} / \mathrm{l}$ & 0.001 & 0.000 & 0.029 & 0.004 & 3 & $-\cdots$ & ---- \\
\hline $\mathrm{pH}$ & --- & 7.480 & 6.700 & 8.440 & 0.385 & $6.5-8.5$ & $6.5-8.5$ & $6.5-8.5$ \\
\hline TDS & $\mathrm{mg} / \mathrm{l}$ & 126.098 & 43.000 & 235.000 & 30.208 & $100-500$ & 1600 & 755 \\
\hline $\mathrm{Ca}$ & $\mathrm{mg} / \mathrm{l}$ & 13.401 & 0.019 & 41.880 & 8.358 & --- & --- & ----- \\
\hline $\mathrm{Mg}$ & $\mathrm{mg} / \mathrm{l}$ & 3.912 & 0.038 & 22.000 & 3.743 & $-\cdots$ & --.-- & ---- \\
\hline $\mathrm{Na}$ & $\mathrm{mg} / \mathrm{l}$ & 20.541 & 0.300 & 69.750 & 9.925 & 100 & & 200 \\
\hline $\mathrm{K}$ & $\mathrm{mg} / \mathrm{l}$ & 1.370 & 0.018 & 13.400 & 1.744 & ---- & $-\cdots$ & $-\cdots$ \\
\hline $\mathrm{CL}$ & $\mathrm{mg} / \mathrm{l}$ & 32.483 & 0.090 & 88.000 & 17.596 & 150 & 250 & 250 \\
\hline $\mathrm{HCO}_{3}$ & $\mathrm{mg} / \mathrm{l}$ & 34.720 & 1.300 & 135.217 & 21.410 & --- & $-\cdots-$ & $-\cdots-$ \\
\hline $\mathrm{SO}_{4}$ & $\mathrm{mg} / \mathrm{l}$ & 23.266 & 0.000 & 90.466 & 16.319 & 150 & 400 & 250 \\
\hline $\mathrm{N}-\mathrm{NO}_{3}$ & $\mathrm{mg} / \mathrm{l}$ & 5.731 & 0.000 & 35.718 & 6.511 & 10 & 10 & 10 \\
\hline $\mathrm{F}$ & $\mathrm{mg} / \mathrm{l}$ & 1.040 & 0.050 & 5.000 & 0.550 & $0.8-1.5$ & 1.5 & 4 \\
\hline $\mathrm{BrO}_{3}^{-}$ & $\mu \mathrm{g} / \mathrm{l}$ & 4.733 & 0.000 & 111.600 & 2.451 & 10 & 10 & 10 \\
\hline
\end{tabular}

\section{Conclusion}

Fifty-two brands of domestic bottled water were collected from the supermarkets and food stores in Riyadh city, Saudi Arabia. The collected drinking water bottles are very different in character, and display a wide range of parameter values. There is a great difference between the determined values of each 
parameter and the respective value labeled in each bottle. Results of $\mathrm{BrO}_{3}^{-}$ indicate that more than $18 \%$ of the total collected bottled water exceeded the allowable limits of Bromate $(10 \mu \mathrm{g} / \mathrm{L})$ according to Saudi Arabia Standards and WHO. Most collected water agrees well with the permissible limits of other parameters set either by WHO or Saudi Arabian standards, but with some variation for some major values.

\section{References}

[1] Guler, C. Evaluation of maximum contaminant levels in Turkish bottled drinking waters utilizing parameters reported on manufacturer's labeling and government-issued production licenses, Journal of food Composition and Analysis. 20: 262-272 (2007).

[2] Baba, A. Erees, F.S. Hicsonmez, U. Cam, S. and Ozdilek, H.G an assessment of the quality of various bottled mineral water marketed in Turkey, Environ Monit Assess. 139: 277-285 (2008).

[3] Guler, C, and Alpaslan, M. Mineral content of 70 bottled water brands sold on the Turkish market: Assessment of their compliance with current regulations, Journal of food Composition and Analysis. 22: 728-737 (2009).

[4] Khan, N. B, and Chohan, A. N. Accuracy of bottled drinking label content, Environ Monit Assess, 166: 169-176 (2010).

[5] Othman A.A, Alansi S.A, and Altufal M. M. Determination of bromate in bottled drinking water from Saudi Arabian markets by HPLC/ICP-MS, Analytical Letters, 43: 886-891 (2010).

[6] Matiti, S.K. Handbook of methods in environmental studies: water and wastewater analysis ABD Publishers. Jaipur (India), (2004).

[7] W.H.O., Guidelines for drinking-water quality, first addendum to third edition, Recommendations vol. 1, W.H.O., Geneva, (2006). 